\title{
The Research on Cartoon Image Design And Application of Main Characters in The Legend of the White Snake
}

\author{
Hu Jiani ${ }^{\text {a }}$, Li Mingzhu ${ }^{2 b \dagger}$, Lu Zhangping ${ }^{3 \mathrm{c}}$, Huang Liqing ${ }^{4 \mathrm{~d}}$ \\ ${ }^{1}$ Art School of Jiangsu University, Zhenjiang Jiangsu, China \\ ${ }^{2}$ Art School of Jiangsu University, Zhenjiang Jiangsu, China \\ ${ }^{3}$ Art School of Jiangsu University, Zhenjiang Jiangsu, China \\ ${ }^{4}$ Art School of Jiangsu University, Zhenjiang Jiangsu, China
}

\begin{abstract}
Cartoon images are one of the important carriers for the inheritance of folk literature and culture. We should pay attention to the positive role of cartoon images in the inheritance of intangible culture. So the study aims to design and develop cartoon images of main characters in the Legend of the White snake based on audience intention. So that the cartoon image can be endowed with historical and modern cultural connotations. In this way, it can play a role in inheriting intangible cultural heritage and enhance the cultural confidence. Through the combination of qualitative and quantitative method, it compared the main characters of the Legend of the White snake at home and abroad. After carrying out desk research on the historical background of the legend, we used the concept of participatory design to conduct a questionnaire survey on the preference of cartoon images and analyzed the problems of character design, carrier, communication, and etc. Finally, based on the audience's extraction and combination of design elements, the cartoon image of the main characters in the Legend of the White Snake was generated, which meets the perceptual needs of modern people. By making full use of the narrative function of cartoon images, the creatively designed cartoon images of the main characters in the Legend of the White Snake are deeply rooted in the hearts of the people. It can also raise public interest in the culture of the White Snake and arouse emotional resonance. In this way, it promotes the inheritance and development of the intangible cultural heritage, the White Snake, and provides a certain reference for the design of cartoon images of similar characters in folk literature.
\end{abstract}

\section{Introduction}

Cartoon language is a worldwide language, which has been characterized by international and cross-cultural communication from the beginning ${ }^{[1]}$. The general cartoon image in the design will be exaggerated deformation, so that it is different from other images characteristics and easy to remember as well as impressive ${ }^{[2]}$. Participatory design is a design activity with a participatory philosophy throughout the research and design orientation, which advocates that all stakeholders of the product, mainly end users including potential users, are invited to participate in all stages of the design activity ${ }^{[3]}$. The purpose is to better understand and meet the needs of users so that a perfect user experience can be created. Therefore, a good cartoon image designed by participatory design is more conducive to the dissemination of culture and the shaping of national spirit, thus promoting the inheritance of classical Chinese culture, which is an important part of intangible cultural heritage and innovative development. Through the research and analysis of the existing the
Legend of the White Snake at home and abroad, this paper interprets the cartoon image design and emotional expressions, it provides some reference for the design of similar folklore culture cartoon image.

\section{Domestic and foreign research status and analysis of the main characters in the legend of the White Snake}

\subsection{Domestic status analysis}

At present, there are different materials on the main characters of the Legend of the White Snake in China, such as texts, illustrations, operas, films and animations, and the mainstream communication channels vary according to the times. We know from field research at relevant White Snake scenic spots that most people in China learned about the legend of the White Snake through the 1992 TV series 'The Legend of the New White Snake'. In the drama, the White Lady is usually clothed in white, with her headdress covered by a white

\footnotetext{
a525668139@qq.com

b50884420@qq.com

clzping@ujs.edu.cn

dhlq@ujs.edu.cn
} 
gauze (Figure 1). In addition to the 1992 cartoon adaptation by Cai Zhizhong, the Legend of the White Snake related to cartoon works is the 2019 anime 3D film 'White Snake: The Legend Begins' widely known. The image of the White Lady in these two versions of the work is also quite different. In the comic, the White Lady is mostly dressed in red with a human snake tail (Figure 2), while in the animated films, the White Lady is more

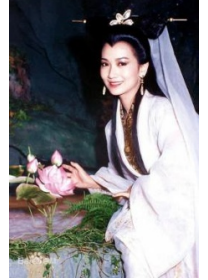

Figure 1:

The TV play Legend of the White Snake in 1992

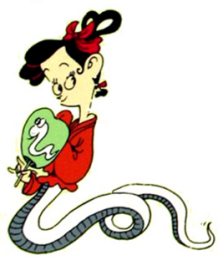

Figure 2: 1992 Cai Zhizhong's adaptation of comics innocent, mainly dressed in white and in the form of a young girl (Figure 3). As a result, the perception of the White Lady character has changed up to the present day. In the field of design, there are also a variety of white snake legend characters with different styles, but most of them are looking for sources and inspiration in the 1992 version of the TV series.

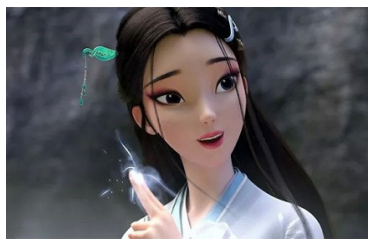

Figure 3:

2019 animated movie White Snake: The Legend Begins

become one of the effective ways for folk literature culture to attract the audience. ${ }^{[4]}$.

\subsection{Foreign status analysis}

As early as the 1950s, the Legend of the White Snake had been told abroad, mostly in Asia and China's neighboring countries. For example, the Japanese film The Tale of the White Snake - Love of Demons, which was co-produced by Dongbao and Shaw Company in 1956, was the film version closest to Feng Menglong's White Lady was Suppressed under Leifeng Tower Forever in China. Among them, the image of the White Lady's appearance is mainly in plain white clothes, with a simple headdress and a kind of unadulterated atmosphere (Figure 4). In 1958, Japanese first colorful animated feature film 'White Snake' was the first time that the Legend of the White Snake appeared abroad in the form of cartoons, in which the image of White Lady was mainly plain white, the headdress was simpler, mostly bud-hair style, and there were two small decorations. However, the image of $\mathrm{Xu}$ Xian reflects the exotic customs, which is quite different from the image of ancient China, and is integrated into the local Japanese culture (Figure 5).
Figure 4: Image of White Lady

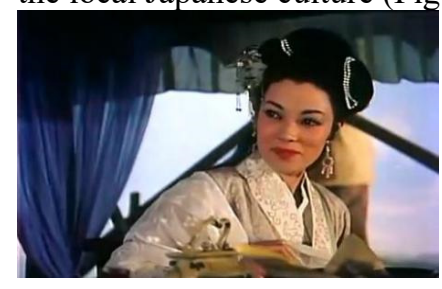
in Japanese Movies

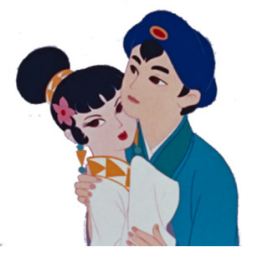

Figure 5: The image in Japanese first color animated feature film
Although the main characters in foreign legends about the Legend of the White Snake are different, their core is the same. It explains the development process of Chinese intangible cultural heritage the Legend of the White Snake, which has expanded overseas and has profound cultural connotations. In the process of folk literature inheritance, some of the main characters involved in this literature appear in the form of cartoons, arousing the audience's goodwill through an emotional appeal with distinct emotions and strong personality, which has

\section{The cartoon image design process of the main characters in the Legend of the White Snake}

\subsection{Overview of design research methods}

In the map of contemporary design research methods produced by Sanders (Figure 6), it is indicated that the two concepts of design research are divided into the expert mindset (shown on the left side of the map) and the participatory mindset (shown on the right side of the map). In the expert mindset, users are seen as research subjects, providing information when needed by designers and researchers, and generally limited to the early research stage and later evaluation stage of the design process. In the participatory mindset, users are seen as partners in the design and development process of the entire project. ${ }^{[5-6]}$. In cartoon image design, the figurative cartoon image design is has been a popular animation style in recent years, that is, cartoon characters are basically designed and positioned according to the proportions and images of real-life characters ${ }^{[7]}$. This kind of design is often based on the subjective impression of the designer (i.e. the expert mindset), and cannot involve the audience. Therefore, participatory design is mainly used in this study to design the cartoon image and increase the audience's participation. Due to the limitation of space, the most representative character in the Legend of the White Snake, the White Lady, is selected as an example. The design process of other main characters is similar to it. 


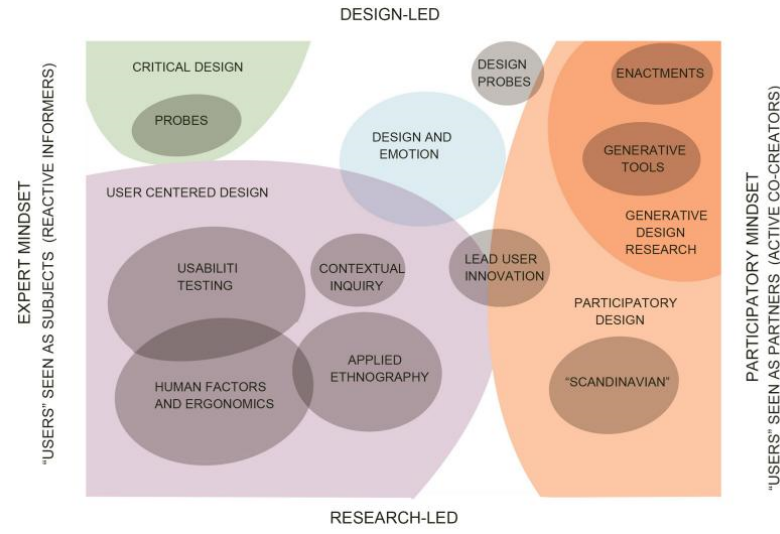

Figure 6: Map of Contemporary Design Research Methods ${ }^{[5-6]}$

First of all, the desktop research method combining qualitative and quantitative methods is adopted to obtain effective information about the characters and refine characteristic elements. At the same time, the Questionnaire Star software is used to make a questionnaire to investigate the audience. Afterwards, the effective information collected will be used to design the creative toolkit, and the audience will be invited to use the creative toolkit to exert their creativity. The designer will make better design decisions based on the output of the respondents. The process as shown in Figure 7.

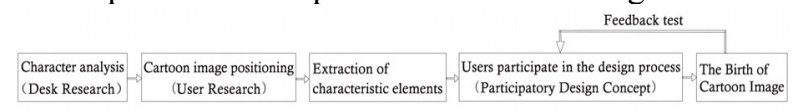

Figure 7: Design Process of Cartoon image of the White Lady

\subsection{Analysis of the characteristics of the main characters in the Legend of the White Snake}

The Legend of the White Snake is one of China's first national intangible cultural heritage, with high folklore and cultural value ${ }^{[8]}$. The storyline of the legend revolves around the central story of 'The the White Snake repays her kindness', which takes place in the Song Dynasty. Under the wonderful compilation of the creators, it not only highlights the characteristics of the characters and tells a rich story, but also reflects some social backgrounds at that time. Therefore, the costumes of the main characters in the Legend of the White Snake should be consistent with those of the Song Dynasty. In the process of inheriting the Legend of the White Snake, with the development of science and technology, there are different ways to tell the story, thus the same theme of the Legend of the White Snake folklore also has different performance characteristics along with the differences in form. The audiences they face will also differ in terms of education level, aesthetic preference, values, etc. Therefore, different versions of 'the Legend of the White Snake' will choose the appropriate expressions according to their own stylistic features and audience needs. Novels generally pay more attention to the logical structure and content of the story, so the depiction of the character image is mostly simple. The ancient books related to the description of the White Lady are collected, as shown in Table 1.

From this, it can be concluded that the image of the White Snake in the novel is mainly characterized by simple white clothes and few headdresses. With the development of society, the characters in The Legend of the White Snake are constantly reshaped and presented through movies and TV shows. It can even be said that with the development of science and technology, inheriting and developing culture through movies and TV shows is one of the main ways of cultural transmission. The questionnaire survey revealed that $75.81 \%$ of the participants learned about the Legend of the White Snake through movies and TV shows. Therefore, the images of the White Lady in movies and TV shows from the 1990s to the present were analyzed (Table 2).

Table 1 Description of the White Snake in Novel

\begin{tabular}{|c|c|}
\hline The literature & Relevant description \\
\hline $\begin{array}{l}\text { Legend of the White Snake } \\
\text { of Tang Dynasty }\end{array}$ & $\begin{array}{c}\text { A widow, 'Sweet and White', 'Beautiful in all its beauty'. White dress } \\
\text { square out, I saw her 'plain skirt, speech spirit elegant, immortal not } \\
\text { extraordinary', looks very beautiful }{ }^{[9]} \text {. }\end{array}$ \\
\hline $\begin{array}{l}\text { The Three Towers of West } \\
\text { Lake in Song and Yuan } \\
\text { Dialect }\end{array}$ & $\begin{array}{c}\text { Xu Xuan saw a beautiful woman in white, 'Green clouds pile hair, snow } \\
\text { coagulation skin'. Her eyes are like waves of autumn water, and her } \\
\text { eyebrows are like the daisies in Spring Mountain. Peach calyx blush } \\
\text { lightly, cherry pearl light purple lip. Cloth shoe lining small golden lotus, } \\
\text { jade finger dew woven bamboo shoots. }{ }^{[10]} \text { All over her body, she wears } \\
\text { white mourning dress. }\end{array}$ \\
\hline $\begin{array}{l}\text { The White Lady was } \\
\text { Suppressed under Leifeng } \\
\text { Tower Forever, by Feng } \\
\text { Menglong in Ming Dynasty }\end{array}$ & $\begin{array}{l}\text { When White Lady appeared on the stage, she 'head wearing mourning } \\
\text { topknot, cloud with some plain hair comb, wearing a collar white satin } \\
\text { shirt, wearing a thin linen skirt', just like a beautiful beauty. }{ }^{[11]}\end{array}$ \\
\hline $\begin{array}{l}\text { Ancient Wu Mo prodigal } \\
\text { son in Qing Dynasty West } \\
\text { Lake Tales }\end{array}$ & $\begin{array}{l}\text { When Xu Xuan looked, but it was a woman wearing white with her } \\
\text { companion in green, holding a bag in his hand, to take the boat. }\end{array}$ \\
\hline $\begin{array}{l}\text { Building a Pagoda on the } \\
\text { Seventh Floor of The Town } \\
\text { Demon by Chen Shuji }\end{array}$ & Its depiction is the same as that in the West Lake Tales \\
\hline Legend of Leifeng Pagoda & How do you think the two women? There is a poem that testifies to this: \\
\hline
\end{tabular}


written by the owner of Jade Mountain in the Qing Dynasty
"The the fog is recessed and the maid's physique is charming, the sunken fish and the wild goose's tiny waist. The two people dressed as masters and servant girl, the master's posture is better and superior.

Table 2 Comparative Analysis of the images about White Lady in movies and TV shows

\begin{tabular}{|c|c|c|c|c|}
\hline \multicolumn{2}{|c|}{$\begin{array}{c}\text { The movies and TV shows image } \\
\text { of White Lady before } 1990\end{array}$} & \multicolumn{2}{|c|}{$\begin{array}{c}\text { The movies and TV shows image } \\
\text { of White Lady after } 1990\end{array}$} & \multirow{2}{*}{$\begin{array}{l}\text { The movies and TV shows } \\
\text { image of White Lady in recent } \\
5 \text { years } \\
\text { [2016] Similar to the } \\
1992 \text { version.Plain } \\
\text { white clothes. } \\
\text { Classic Features } \\
\text { White Veil. }\end{array}$} \\
\hline & $\begin{array}{l}\text { [1926] The costumes are } \\
\text { mainly opera } \\
\text { costumes.Black and white } \\
\text { data unclear dress color. } \\
\text { Estimated to be plain white } \\
\text { dress. } \\
\text { Traditional bun hairstyle. }\end{array}$ & & $\begin{array}{l}\text { [1990] Simpler clothing. } \\
\text { Ancient costume.Dressing } \\
\text { up like in Song Dynasty. } \\
\text { Plain white clothes. } \\
\text { Traditional bun hairstyle } \\
\text { with less headwear. }\end{array}$ & \\
\hline & $\begin{array}{l}\text { [1939] The costumes are } \\
\text { mainly opera costumes. } \\
\text { There are many patterns in } \\
\text { clothes.Traditional bun } \\
\text { hairstyle with more } \\
\text { headwear. }\end{array}$ & & $\begin{array}{l}\text { [1992] Simpler clothing. } \\
\text { Ancient costume.Dressing } \\
\text { up like in Song Dynasty. } \\
\text { Plain white clothes. } \\
\text { The hairstyle between } \\
\text { traditional bun and } \\
\text { shoulder-length. } \\
\text { Classic Features White } \\
\text { Veil. }\end{array}$ & $\begin{array}{l}\text { [2018] Ancient } \\
\text { costume. } \\
\text { Dressing up like in } \\
\text { Song Dynasty. Plain } \\
\text { white clothes. The } \\
\text { hairstyle between } \\
\text { traditional bun and } \\
\text { shoulder-length. }\end{array}$ \\
\hline & $\begin{array}{l}\text { [1953] Simpler clothing. } \\
\text { Ancient costume.Dressing } \\
\text { up like in Song Dynasty. } \\
\text { Plain white clothes. } \\
\text { The hairstyle between } \\
\text { traditional bun and } \\
\text { shoulder-length. }\end{array}$ & & $\begin{array}{c}\text { [1993] Simpler } \\
\text { clothing. } \\
\text { Ancient costume.Dressing } \\
\text { up like in Song Dynasty. } \\
\text { Plain white clothes. } \\
\text { The shoulder-length } \\
\text { hairstyle. }\end{array}$ & $\begin{array}{c}\text { [2019] Ancient } \\
\text { costume. } \\
\text { Dressing up like in } \\
\text { Song Dynasty. Plain } \\
\text { white clothes. The } \\
\text { shoulder-length } \\
\text { hairstyle. }\end{array}$ \\
\hline & $\begin{array}{l}\text { [1955] The costumes are } \\
\text { mainly opera costumes. } \\
\text { There are less patterns in } \\
\text { clothes } \\
\text { Traditional bun hairstyle. } \\
\text { More small decorations. }\end{array}$ & & $\begin{array}{l}\text { [1995] Simpler clothing. } \\
\text { Ancient costume.Dressing } \\
\text { up like in Song Dynasty. } \\
\text { Plain white clothes. } \\
\text { The hairstyle between } \\
\text { traditional bun and } \\
\text { shoulder-length. }\end{array}$ & $\begin{array}{c}\text { [2019] Plain white } \\
\text { clothes. The hairstyle } \\
\text { between traditional } \\
\text { bun and shoulder- } \\
\text { length. }\end{array}$ \\
\hline & $\begin{array}{c}\text { [1956 Japan] Simpler } \\
\text { clothing. Ancient costume. } \\
\text { Exotic customs. } \\
\text { Plain white clothes. } \\
\text { The hairstyle between } \\
\text { traditional bun and } \\
\text { shoulder-length. } \\
\end{array}$ & & $\begin{array}{l}\text { [2003] Simpler clothing. } \\
\text { Ancient costume.Dressing } \\
\text { up like in Song Dynasty. } \\
\text { Plain white clothes. } \\
\text { The hairstyle between } \\
\text { traditional bun and } \\
\text { shoulder-length. }\end{array}$ & \multirow{2}{*}{$\begin{array}{l}\text { [2019] Simpler clothing } \\
\text { Ancient costume } \\
\text {.Dressing up like in Song } \\
\text { Dynasty. Plain white clothes. } \\
\text { The hairstyle between } \\
\text { traditional bun and shoulder- } \\
\text { length. } \\
\text { Fewer simple headpieces }\end{array}$} \\
\hline & $\begin{array}{l}\text { [1958 Japan] Ancient } \\
\text { costumes, exotic cultures. } \\
\text { Oversized sleeves, long } \\
\text { skirt, plain white. } \\
\text { Flower buds on head. }\end{array}$ & & $\begin{array}{l}\text { [2005] Simpler clothing. } \\
\text { Ancient costume. Dressing } \\
\text { up like in Song Dynasty. } \\
\text { Plain white clothes. } \\
\text { The hairstyle between } \\
\text { traditional bun and } \\
\text { shoulder-length. }\end{array}$ & \\
\hline & $\begin{array}{l}\text { [1962] The costumes are } \\
\text { mainly opera costumes. } \\
\text { The clothes mostly in } \\
\text { white with less patterns. } \\
\text { Traditional bun hairstyle. } \\
\text { More small decorations. }\end{array}$ & & $\begin{array}{l}\text { [2008] Simpler clothing. } \\
\text { Ancient costume.Dressing } \\
\text { up like in Song Dynasty. } \\
\text { Plain white clothes. } \\
\text { The hairstyle between } \\
\text { traditional bun and } \\
\text { shoulder-length. }\end{array}$ & $\begin{array}{l}\text { 【1)】 Before 1990, White } \\
\text { Lady's movies and TV shows } \\
\text { images were mostly opera } \\
\text { costumes, with more } \\
\text { complicated costumes and } \\
\text { headdresses, mostly with } \\
\text { traditional bun hairstyle. }\end{array}$ \\
\hline Gats & $\begin{array}{l}\text { [1962] The costumes are } \\
\text { mainly opera costumes. } \\
\text { The clothes mostly in } \\
\text { white with more patterns. } \\
\text { Traditional bun hairstyle. }\end{array}$ & & $\begin{array}{l}\text { [2009] Dressing up like in } \\
\text { Song Dynasty. Plain white } \\
\text { clothes. } \\
\text { The hairstyle between } \\
\text { traditional bun and } \\
\text { shoulder-length. }\end{array}$ & $\begin{array}{l}\text { 【(2) After 1990, the image } \\
\text { is closer to Song Dynasty } \\
\text { women, and the costumes are } \\
\text { more simple and generally } \\
\text { white, in line with modern } \\
\text { aesthetics. }\end{array}$ \\
\hline & $\begin{array}{l}\text { [1975] Simpler clothing. } \\
\text { Ancient costume.Dressing }\end{array}$ & & $\begin{array}{l}\text { [2010] Simpler clothing. } \\
\text { Plain white and black }\end{array}$ & 【(3) In the past five years, \\
\hline
\end{tabular}




\begin{tabular}{|c|c|c|c|c|}
\hline & $\begin{array}{l}\text { up like in Song Dynasty. } \\
\text { Plain white clothes. } \\
\text { Traditional bun hairstyle. }\end{array}$ & & $\begin{array}{c}\text { clothes. } \\
\text { The hairstyle between } \\
\text { traditional bun and } \\
\text { shoulder-length. }\end{array}$ & $\begin{array}{l}\text { the movies and TV shows } \\
\text { images of the White Lady } \\
\text { have mostly resembled the } \\
\text { costume of a female warrior }\end{array}$ \\
\hline & $\begin{array}{l}\text { [1978] Simpler clothing. } \\
\text { Ancient costume.Dressing } \\
\text { up like in Song Dynasty. } \\
\text { Plain white clothes. } \\
\text { Traditional bun hairstyle. }\end{array}$ & & $\begin{array}{l}\text { [2011] Simpler clothing. } \\
\text { Ancient costume.Dressing } \\
\text { up like in Song Dynasty. } \\
\text { Plain white clothes. } \\
\text { The hairstyle between } \\
\text { traditional bun and } \\
\text { shoulder-length. }\end{array}$ & $\begin{array}{l}\text { dressed in white, retaining a } \\
\text { small amount of the costume } \\
\text { characteristics of Song } \\
\text { Dynasty women, in line with } \\
\text { modern aesthetics. }\end{array}$ \\
\hline 18 & $\begin{array}{l}\text { [1980] The costumes are } \\
\text { mainly opera costumes. } \\
\text { The clothes mostly in } \\
\text { white with many patterns. } \\
\text { Traditional bun hairstyle. }\end{array}$ & की & $\begin{array}{l}\text { [2012] Simpler clothing. } \\
\text { Ancient costume.Dressing } \\
\text { up like in Song Dynasty. } \\
\text { Plain white clothes. } \\
\text { The shoulder-length } \\
\text { hairstyle. }\end{array}$ & $\begin{array}{l}\text { Note: The } 1949 \text { and } 1952 \\
\text { editions do not have any film } \\
\text { or video material available. }\end{array}$ \\
\hline
\end{tabular}

It is not difficult to find from the table that before the 1990s, "White Lady" was mostly dressed up in opera costumes and makeup, with very complicated headdresses. After that, the image is closer to that of women in the Song Dynasty. The costumes are relatively simple, with white as the main color. The common image elements in 27 movies and TV shows have been marked in red. Since there are many changes in the image of the White Lady in movies and TV shows, only the most classic image is selected here for analysis. It can be seen from Table 2 that the elegant white clothes are the representative elements of the White Lady. There are three types of hairstyles, namely the traditional bun hairstyle, the shoulder-length hairstyle, and the hairstyle in between. Their headdresses are also different, with white veil appearing twice.

\subsection{Positioning of cartoon image design}

At present, some domestic cartoon characters are mostly aimed at younger children. However, Japanese animation is not only for children, but for people of all ages and is sought after by all groups ${ }^{[1]}$. So the cartoon image designed here should be aimed at a wide range of groups. Taking into account the differences in the perception of "white snake" by audiences of different genders and ages, the public's perception of "White Lady" and their satisfaction with the existing images of "White Lady" were investigated through questionnaire surveys and analysis of related influencing factors. The target population is a group of young people with a high level of science and technology and certain purchasing power. The purpose is to find out the image of the White Lady which is most suitable for people at this stage through the questionnaire survey of the public. A total of 64 questionnaires were distributed and 62 were valid, among which $9.38 \%$ were the post-2000 generation, $84.38 \%$ were post-90s, and $6.26 \%$ were post- $60 \mathrm{~s}$, post-70s and post-80s. Through investigation, it is found that $66.67 \%$ of people think that "white" is the most representative element of the classic image of the White Snake. And when participants describe the White Snake in their own way, the word "white" appeared most frequently. As for the choice of hairstyles, $88.71 \%$ of the people chose the hairstyles of the 1992 TV series. Most of these people are post-90s generation and most of them have only seen this
TV series. They understand the Legend of the White Snake is also by this TV series. As mentioned above, the costumes of the main characters in the Legend of the White Snake should be consistent with those of women in the Song Dynasty, so the costume and makeup elements in Song Dynasty should also be considered when designing cartoon images.

\subsection{Refinement and analysis of distinctive elements}

According to the composition of the cartoon character image, the related elements were sorted out (Table 3 ) and planarized. For the head part, 10 kinds of traditional female classic hairstyles in Song Dynasty were selected and flat designs were implemented (Figure 8). Through the analysis of the characteristics of the White Lady, it can be seen that neither the bun hairstyle with corolla nor the high-bun hairstyle in the Song Dynasty is suitable for the image of the White Lady. Therefore, the remaining 5 kinds of classical hairstyles in the Song Dynasty and 5 hairstyles of the images of the White Lady in movies and TV shows were chosen for the next step (Figure 9). In order to resonate with the audiences, they were asked to choose the hairstyle of the White Lady from these options.

Table 3 Elements classification of main characters in the Legend of the White Snake

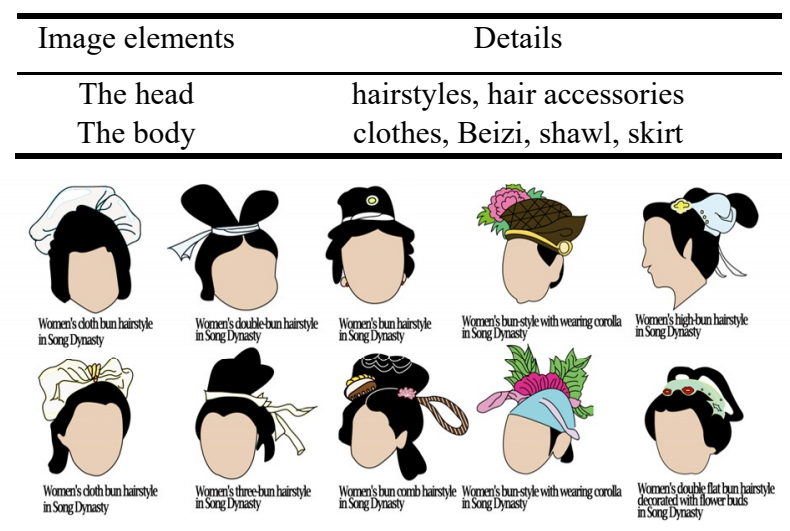

Figure 8: Traditional female classical hairstyle in Song Dynasty 


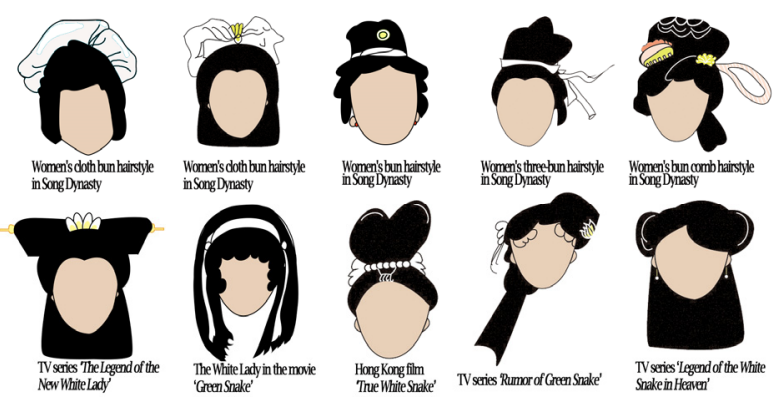

Figure 9: Unified angle cartoonish head processing

Similarly, for the body part of the character, the audiences also participated in its design. From the research, we know that the blouse was the top form of women's clothing in the Song Dynasty. It was a kind of outerwear with narrow cuffs, and its collar style included round collar, cross collar and placket ${ }^{[12]}$. It was the most common style of clothing worn by women in the Song Dynasty because it had a wide circulation ${ }^{[12]}$. The skirt is the most common lower garment worn by women in ancient China, and the skirt worn by women in the Song Dynasty are also very representative ${ }^{[12]}$. Accordingly, six kinds of cartoonish costumes conforming to the characteristics of the Song dynasty clothing were designed for the audiences to choose, and the accessories and colors were all simple and light, which were more in line with the characteristics of the image of the White Lady (Figure 10).

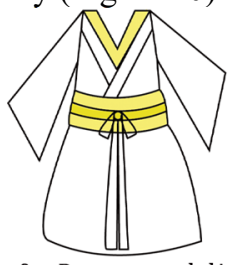

Song Dynasty cross-neck shirt

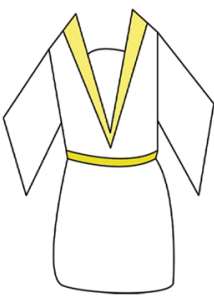

Song Dynasty cardigan vest

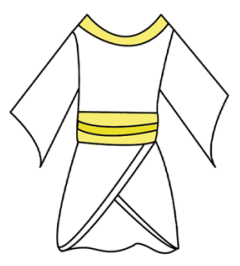

Song Dynasty round collar shirt

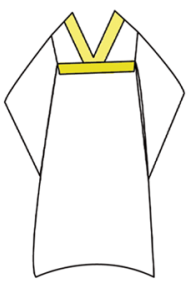

Song dynasty chest-flush skirt SongDynastyround collar half sleeve shir
Figure 10: Cartoonish costumes in line with Song dynasty characteristics

\subsection{Users participate in cartoon image design}

The main idea of participatory design is to try to involve those who will be 'users' throughout the design and development of the project. One of the key features is to provide users with physical artifacts to help them be creative and express their thoughts and feelings by making things ${ }^{[3]}$. These thoughts and feelings are invisible needs, so researchers need to focus on 'what people make' or 'what is made'. Therefore, a creative toolkit was created by the extracted distinctive elements were materialized, and respondents (i.e. target population) were invited to participate in the design (Figure 11).

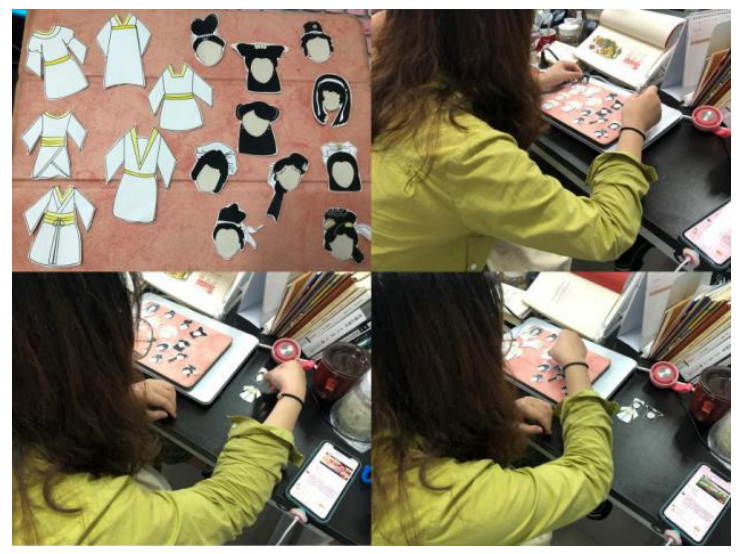

Figure 11: User participation in part of the image design process

Spiritual participation generally means that users get emotional resonance and imagination space from products $^{[13]}$. Through the questionnaire survey, users can also get more spiritual participation, so that the designed image can be closer to the audience. Among the valid questionnaires, $87.1 \%$ of users prefer simple and generous cartoon style and $54.84 \%$ of users chose the relatively simple crayon cute style in the question of cartoon style preference (Figure 12), so the keynote of cartoon style is relatively simple when designing. In terms of hairstyle design, $45.90 \%$ of users chose the Song Dynasty cloth bun hairstyle and $72.13 \%$ of users chose the hairstyle of the White Lady in the 1992 version of the TV series, so the typical elements of the two hairstyles were extracted and combined. In the aspect of head accessories, $50.82 \%$ of users chose the image in the animated movie White Snake: The Legend Begins as a reference. In terms of clothing, the cross-neck shirts and skirts of the Song dynasty (selected by $73.77 \%$ of users) were directly selected. Therefore, the final cartoon image generated by the preliminary study is shown in Figure 13.

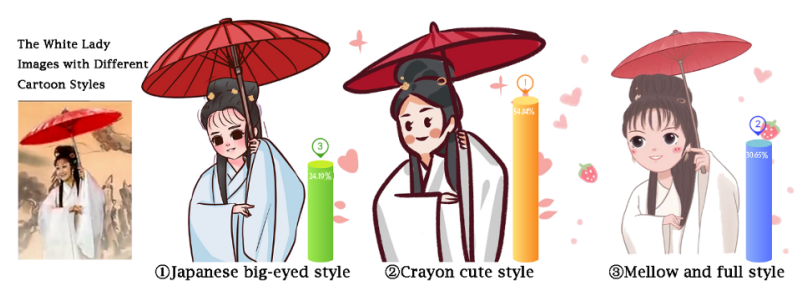

Figure 12: Cartoon style preference survey results
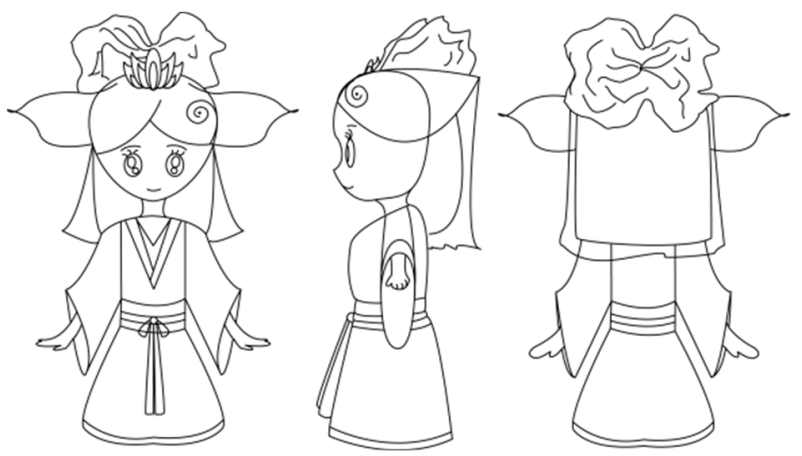


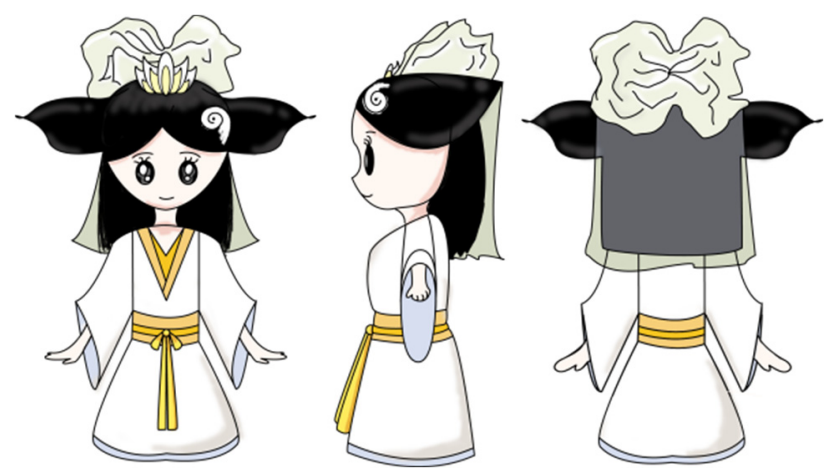

Figure 13: The final cartoon image of the White Snake

After the image was formed, it was distributed to some of the users who had participated in the preliminary survey and those who used the creative toolkit to create the image. Most of them thought that the image was more consistent with the image of the White Lady in their minds which means the design feedback was relatively good.

\section{The Application of Cartoon Images of Main Characters in the Legend of the White Snake}

Cartoon images can also be described as a graphic with cultural connotations and therefore can be linked to a variety of media. In modern society, a successful cartoon image is not only the shape of the classic, the subsequent promotion and industrial extension are also more important magic ways to make cartoon images immortal ${ }^{[1]}$.One scheme that can be effectively promoted and industrialized is to create cultural and creative products. As the name implies, a cultural product is a product that originates from the corresponding cultural theme and transformed through the creativity of the designer, thus giving the product cultural connotation and a certain market value. In short, a cultural product is a kind of outcome of cultural creativity. Cultural creative products can be broadly divided into three categories: daily necessities, decorative souvenirs, and technologybased products. Therefore, the cartoon images of the main characters of the Legend of the White Snake, which are designed with the participation of users, could be used to develop cultural and creative products, so that the nonheritage culture of the White Snake can be transformed into products and the culture can be effectively disseminated through the circulation of products.

\subsection{Positioning for the cultural and creative product design of the cartoon image of the main characters in the legend of the White Snake}

Through the questionnaire survey of 64 potential consumers (i.e. users who participated in the previous White Lady image research), a total of 62 valid questionnaires were collected. Among them, 63.93\% of the participants were willing to buy cultural and creative products based on the cartoon image of the White Lady. And the price of cultural and creative products they accept is mostly ranged from 0 to $100 \mathrm{RMB}$. According to the survey, most of the participants want to buy stationery, daily necessities and decoration supplies (Figure 14), and most of them are post-90s. They usually buy cultural and creative products to improve the quality of life. Also, most of the target users are interested in the cultural and creative products which embody the cultural connotation but are also lovely and modern. And most of the participants prefer wood and cloth as the main materials for cultural creative products. As for the views of on cultural innovation in The Legend of the White Snake, most of the participants like the ways which reflect the original cultural characteristics, combine with daily necessities and have lovely and modern images.

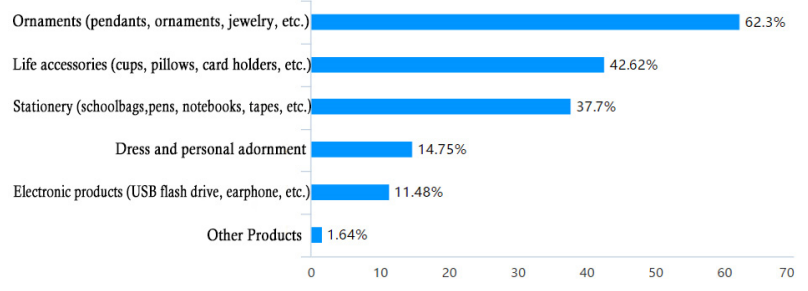

Figure 14: Survey results of popularity of creative product

\subsection{Application of White Lady cartoon image design}

It is found that daily necessities and school supplies account for a large share of the domestic and foreign cultural and creative markets, because they are not only consumer goods in people's daily work, but also essential for students. Moreover, most of these products are easy to mass produce, such as mugs, bags, pillows, key chains, etc. These cultural and creative products generally pay attention to the combination of form and cultural content, which should be creative and interesting. Therefore, when designing cultural and creative products derived from traditional culture, we should not only consider promoting the development of this culture, but also add artistic value to the products. Therefore, according to the results of the questionnaire survey, the cultural design and creative products of the White Lady's cartoon image are as follows (Table 4).

Table 4 Cultural and creative products of White Lady cartoon image

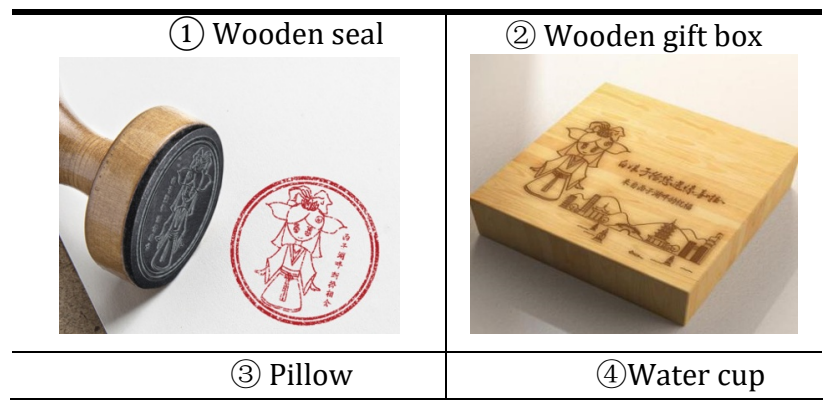




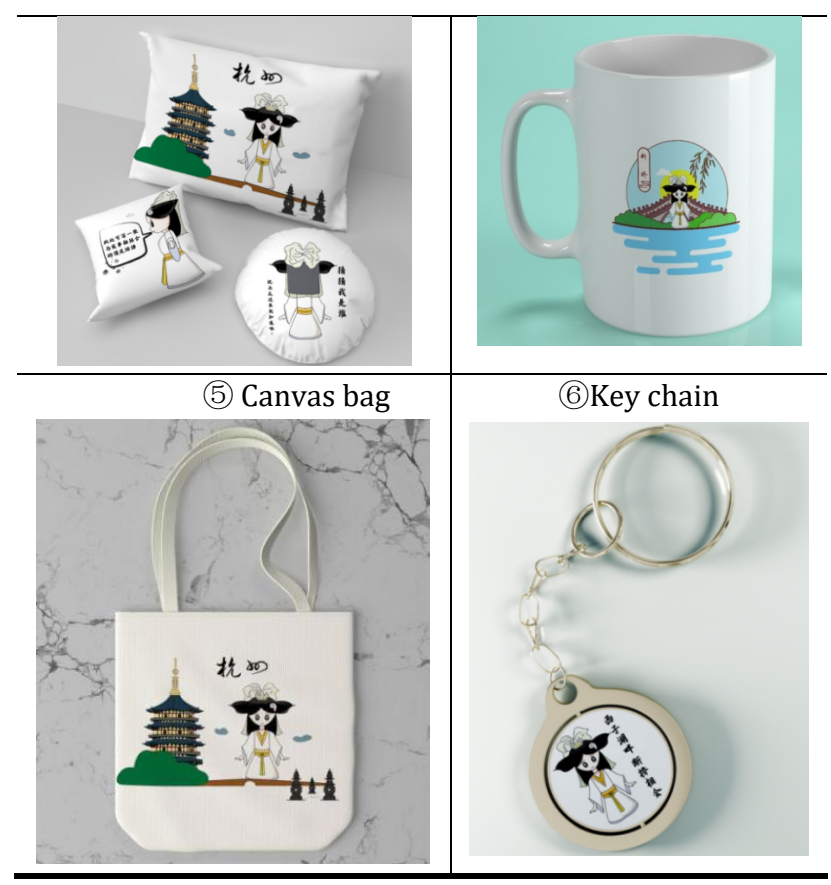

Of course, the application of cartoon images is far more than that. With the development of science and technology, cartoon images can be applied in a wider range. New media, virtual reality and augmented reality products can all be generated based on cartoon images, which shows that excellent cartoon images have farreaching significance for cultural communication.

\section{Conclusion}

It can be said that cartoon is an art that merges tradition and innovation. A good image design is essential for the effective inheritance of excellent folk literature works. Through research and data collection, this paper takes the White Snake (White Lady) as an example to classify and summarizes its image characteristics. Using the concept of participatory design and a combination of qualitative and quantitative methods to involve users in the design, it develops the cartoon image of the White Lady and its creative products. The design of the other main characters in the Legend of the White Snake is similar to it, which can be adjusted according to public cognition and other factors. Through the audience's participation in the image design process, the public's interest in the Legend of the White Snake has been aroused and the inheritance and development of the intangible cultural heritage 'The Legend of the White Snake' have been promoted, so as to provide some reference for the design of cartoon characters of similar folklore characters and to inherit the excellent culture.

\section{ACKNOWLEDGMENTS}

This Work is supported by the University-Industry Collaborative Education Program, China (Grant No. 201902177003) and Research Project of Philosophy and Social Science Research in Colleges and Universities in Jiangsu Province, China (Grant No. 2018SJA1081).

\section{REFERENCES}

1. DUANMU Dan-qing. Reflections on Chinese Zodiac Image Design[J]. Art Panorama,2019(12): 230-231.

2. LIU Ping-yun, HU Chuan-ni. Cartoon image of the role in the use of marketing[J]. Art Journal,2003, (4): 52-53.

3. BELLA Martin, BRUCE Hannington. General design method [M]. Trans. CHU Xiao-hua. Beijing: Central Compilation and Translation Press, September 2013.

4. SUN Ya-yun, BAI Yu-ping. Design and Dissemination of Campus Culture Cartoon Image[J]. Packaging Engineering,2018,39(22):72-76.

5. Elizabeth B N S. Design Research in 2006: Design Research Quarterly[C]. 2006: 1-9

6. JIANG Lu-jun. Application of User Participatory Ideas in Children Corrugated Cardboard Furniture Design[J].

7. LI Li. Analysis of Cartoon Image Design [J]. Art and design (Theory), 2009 (05): 235-237.

8. LIU Shou-hua. Intangible Cultural Heritage Protection Project and Chinese Folk Literature[J]. Journal of Central China Normal University (Humanities and Social Sciences Edition), 2011, 50(05): 103-107.

9. [Tang] GU Shen-zi, XUE Yong-ruo, Bo Yizhi-Jiyi Ji [M]. Beijing: Zhonghua Book Company,1980.

10. CHENG Yi-zhong. Storybook of Novelists in Song and Yuan Dynasties (Part 1) [M]. Jinan: Qilu Book Society, 2000.

11. XIAO Xin-qiao. Selections of Ancient Vernacular Novels by West Lake[M]. Hangzhou: Zhejiang Literature and Art Publishing House, 1984.

12. TIAN Tian. FEMININE COSTUME OF THE SONG DYNASTY AND CULTURAL IMPLICATIONS[D]. Shandong University Of Arts, 2015.

13. SHI Jia-lu, YU Shu-lan. Research on cultural and creative product design under the concept of participatory design $[\mathrm{J}]$. Furniture and interior decoration, 2018 (09): 26. 